dividing all the structures and all ligaments so that the limb was only attached by the component parts of this anterior flap here and then turning it up. Now then, to get the saw applied at the junction of the anterior and middle third, a person will notice on himself, why he misses the head of the fibula, as the fibula remains on this part of the leg which drops away. It remains on the part of the leg which falls away and does not come into consideration at all.

\section{THE PUBLIC SCHOOL AND ITS DEFECTS, IN RELATION TO HEALTH.}

Read in the Section on Dental and Oral Surgery, at the Forty-sixth Anuual Meeting of the American Medical Association,
at Baltimore, Md.. May 7-10.1895.

BY T. S. WATERS, D.D.S.

BALTIMORE, MD.

I will consider this subject under the following three heads:

1. The pathologic effects upon the system and the teeth of young ladies from cramming, crowding and overworking the brain without a proper amount of physical development in the open air to counteract the loss of nervous force. 2 , the evil results therefrom, the effect produced upon the future mothers of this great and glorious country. 3, what are we doing as physicians and dentists to counteract this influence, outside of applying remedies to relieve and restore the broken down subject?

Should we not as members of the healing art, write and read papers upon this subject, discuss the same that the public through the daily press; may be so impressed that public sentiment will cause a reaction in the matter and the Heads of our educational institutions be made to halt, and modify their system of teaching which has proven for a quarter of a century so very deleterious to the physical and mental growth of our generation? School crowding and cramming impairs the health and lessens the appetite, which causes imperfect nutrition, bad assimilation of food and of ideas. This, therefore, lessens appropriations of good amounts of food which should consist of a proper amount of phosphates, with lime salts for the growing child, the very want of which retards and impairs the development of the second growth of teeth, of hair, nails and bones. These crowning beauties are the very evidence of health. On the other hand consider cramming, crowding and forcing as they are practiced in school life, especially in the high schools, when the young girl is just budding into womanhood, when her nervous system is in the most critical condition, when we frequently find instances in which a dormant tendency to mental diseases becomes aroused into action, and acute mania forms one of the risks through which many young women have to pass, at the age of puberty. As soon as any symptoms of eccentricity display themselves, at once the parents or the physician should interfere and relieve such pupils from study and school, for this crowding and cramming tends to the deterioration of the development of the teeth, and the whole body frame. From this rachitic condition of the teeth, as in imperfect bony union after fracture, the administration of phosphates, lime salts, etc., is of great assistance to aid the young and bony columns to attain their full size and strength. Exercise, sunlight, air, rest and short lessons, with a small class in charge of a competent teacher, who restricts studies to school hours, by day, would tend to a more salutary condition.

The new diseases, nervous exhaustion or prostra- tion, like the defective teeth of the young, the pale blood of chlorosis, rickets, chorea and tooth decay, is in a general measure mainly due to the over-strain of the young mind in search of knowledge in school, and sad to relate many pupils pass the door, who leave their health within the college walls, too feeble to develop the higher dreams of ambition and thus disappoint the hopes of parents and lovers. It is unnecessary to describe the unhealthful effects of vitiated air upon the system of human beings in order to show the necessity for the work in hand, aside from the wellknown direct effects of bad air, slight physical ailments of children, wholly unnoticed, are often developed by the impurities of the air of our schoolroom into serious diseases. In the public schools of Baltimore, like other large cities, in many storied buildings surrounded by alleys, and over-crowded with children trying for a primary education, with defective ingress and exit, although trained to march and counter march, to gymnastic exhibitions, and trained to fire-alarms under the command of their chief; yet in case of fire many may perish. Under the sudden influence of alarm from fire, if panic-stricken, what is the dire result? The tumultuous crowd without reference to order or previous instructions are rendered insane, and inoperative and the consequence is a fearful destruction of life and limb. All this could be saved by the return to our primitive form, the country school, viz.: Every precinct in each ward of our cities should have a reproduction of one-storied buildings, and plenty of fresh water and air; the interior containing study, class and teachers' room, suitable to accommodate 75 to 100 pupils, with 25 to 50 scholars to the teacher and assistant; with direct light from four sides, and ventilation from every direction. In this subdivision of school, it might be argued that extra expense would be objected to. There can be no expense in a business way, which would be compensated by the superior results in the improvement of education of our children, both mentally and physically, for the benefit of the nation, for what is the nation's expenditure to the country's good? The history of an individual education is but a unit, the history of a nation's education is the combination of all the units. We must remember that the teeth, hair and nails are the usual inheritance of our male ancestry; but heroism, pride and valor are emblems of the maternal side. The mother is the teacher of religion and proper speaking, all of which is taught at the altar, the mother's knee; hence, she is the instructor of the future nation, making good the adage that the "hand which rocks the cradle rules the world." "These are my jewels" said Cornelia, when she gave her sons to defend the nation. The dangers of over-crowding study on the coming mother, from a nervous standpoint, are well worthy of our consideration.

Neurasthenia saps the nervous enery that should be devoted toward fitting her for motherhood, within the next few years, when her greatest development in mind and body should be perfected. Hysteria is the most prolific source of domestic infelicity. Although the immortal Dante could in imagination descend to the uttermost bounds of Tartarus, and in vivid colors depict the state of the damned, yet would his pen have been wholly powerless to describe the bodily torment and agony of spirit of the unhappy victim of this dread affliction, where strong nature yields her powers to unnatural nervous prostration. How often do we see some fair young creature, whose 
rounding muscles and graceful contours bespeak the budding woman, subject by reason of a peculiar nervous organization to St. Vitus dance-that peculiar involuntary twitching of the most diverse groups of muscles, especially peculiar to school girls; such torture, the iron hand of the Spanish inquisition would have been powerless to inflict. Much attention is being directed to some of the defects of our public schools, which were but a few years ago regarded as the perfection of education. As to the proper location and structure of the building, and the method of heating and lighting, ventilation and safety from fire and panic and the danger resulting from the shock to the nervous system, these I shall not discuss. I desire, however, to point out that nervous dyspepsia is common to the public school of higher grades. Defective appetite, deficient assimilation, constipation and mal-nutrition impoverish the blood, the gastric juice, the bile and the tissue forming materials. Hence the children lose their desire for food and regularity, and complain of lassitude, with marked cravings for such stuff as suits them least; cheap candies, pickles and chewing gum, slate pencils and fuller's earth. This boulimic state of the appetite fails to afford nourishment to the growing, and commonly entails a bad habit that often continues until maturity, which should be the age of perfection and beauty under happy circumstances of health. These unhappy surroundings, render them feeble in mind and body, with a tendency to chorea, epilepsy and anemic condition of the growing boy, and chlorisis of the girl. Hence full development can never be acquired until the cause of such arrest shall have been removed. We want no walking libraries of our children, with straps holding a dozen books; to study at late hours by bad gas light, when they should be asleep in a well ventilated room.

There should be laws forbidding the deadly practice of cramming, crowding and forcing the young and tender mind out of all proportion; all reason, all common sense, urged on with the foolish idea that he or she may gain the prize, a miserable fad that destroys the happiness and future prospects, be it a worthless story book or a gold medal; it is a cheat and a snare. The moral obligation of every true physician and dentist should prompt him to act speedily and forcibly in this matter and join with the mighty voices of great sanitarians; for the time is propitious, the demand is urgent and if we fail to meet the emergencies we are cowards, unworthy to bear the title of Doctor, viz., members of the great healing art, which prevents as well as rectifies diseases.

In the schools, personal contact is unavoidable, and the susceptibility of the children is so great, that many must fall victims to infectious diseases. There are several methods of carrying contagion unwittingly. The school books are usually covered with muslin, worsted or cloth, and are frequently returned to school, after having been in the possession of children who have been ill with infectious diseases. The indiscriminate use of slate and lead pencils by the children is another source of disease. The washing of the slates with saliva is not an improbable method of disseminating diphtheria and other diseases. In the higher grades, it is now the custom in many of the schools to use paper pads and lead pencils, but even here the moistening of the points of the lead pencils with the tip of the tongue may be the means of transmitting certain diseases. The improper storing of the children's outer garments is another source of danger.
Isolation and disinfection are the chief means to be employed by sanitarians for overcoming infectious diseases. Slates and slate pencils should be discarded entirely, and the pencils or pens supplied to the pupils should be individual property. Books should never be covered with any texile fabric, but with stout glazed paper. The outer clothing of the children should be placed in closets outside of the class room, and should be in some way disinfected while there. The children should be compelled to come to the class room with clean faces, hands and nails. Many teachers are very watchful and are often very quick to deteet infectious diseases. A mild attack of scarlet fever or measles is popularly considered to be non-contagious, and hence such children are often returned to the schools before they have recovered. Such practice can not be entirely avoided. Every child found to be suffering from sore throat should be immediately sent home, and not allowed to return to the school until well. It has been the custom of the board of health to keep the principals of the schools informed as to what localities within a certain distance of the school are infected. All of the school children are required to present vaccination certificates, or to be vaccinated if this has not been done for seven years. According to the rules of the department, the board of health does not perform such vaccination, except with the consent of the parents or the guardians of the children.

The oppressive tasks of the public schools, the unnatural requirements of moderm society, fed, as it is, by depravity in all its forms, stimulate the passions and affective faculties, bringing a constant tension and strain on the understanding and invite insanity by way of many nerve channels, which did not formerly exist. These are the principal causes of the increased number of neurotic troubles, and should be the subject for serious reflection of the dentists, physicians, moralists and the government. This can not be safely disregarded. We must make a halt in these rapid proceedings, to contemplate a way of action for better things. Let us try in some degree to imitate the rural advantages of health.

Now note the difference in favor of the country schoolboy as he plods his way to the school-house, surrounded with shade and supplied with sparkling spring water; how he arrives at school happy and bright in the ruddy glow of health, his study being confined to the hours of the school; no books to carry back and forth, strong and active; while his city cousin but keeps alive with little color and less vigor, poor appetite, can not hold a semblance of the country boy, who has constant outdoor exercise, simple wholesome food, with the very best of appetite, grandest digestion, no dyspepsia, no constipation, no sallow skin, no carious teeth to mar his manly appearance or drive him to distraction; he grows apace with the weeds, well developed in body and mind, helping to make the record of such schoolboys as were Washington, Jefferson, Madison, Webster, Clay, Franklin and Adams; of such nobility our nation should be proud. It is of record that these men had noble mothers, all Cornelias pointing to her living jewels, and like the mother heroine declaring that rather than see her boys cowards or hirelings she would sooner see them brought back to her on the point of their swords; such mothers make noble sons, and such sons make noble nations; such mothers can come from no pale chlorotic schoolgirls as we see now, nor can they replace their 
sires with the hardy generation which gained our independence. They must be healthy, vigorous; must have at the beginning of their pregnancy all the important conditions occurring in the make-up of women of their former grandames. This is not only important by reason of the peculiar conditions arising in the mother, but possesses a deeper meaning when we consider the new relationship which will soon spring up by means of a factor in the child. The mother is now called on to a renewed physiologic condition of existence. She has grown and lived for herself alone heretofore. She has to create and live for another, which must depend upon and derive its sole subsistence from the maternal blood, and if this blood is not of the strongest elements, that mother had better never be a mother. The healthy mother makes and keeps a strong healthy child. The mother who fails to nourish the child through want of strength, lack of milk or affection, is sure to lose the affection of that child. The lack of affection means neglect and loses to the nation its best hold on its children. Thus when we are confronted with the fact of how far our schoolgirl life is a perfect one in point of development and health, we say nothing of the morals; thus to have a healthy society formed only of healthy factors, these factors being mainly healthy, vigorous mothers; for the father may be but the pigmy of a man, and yet impart the germ of the healthy being, which the mother goes on perfecting, viz., such mothers as those of our forefathers who fought for and gave to us our independence. Such perfection of mind and physical development could never have resulted from the forced environments of the public schools, as now found in all our large cities.

From the crowding, the cramming and the prize seeking policy of our present system of public schools, give the growing girl freedom from too much restraint, give her ozone in abundance, plenty of room, plenty of light, plenty of bicycling, good company; allow mixed society, free expression, boots, spurs and hats, horseback and rowing; and you will create the coming woman with broad hips, big bones, full brow, courage like the lion and virtue like Bessemer steel.

\section{A NATIONAL SANITARIUM FOR CON- SUMPTIVES. \\ BY W. THORNTON PARKER, M.D. GROVELAND, MASS.}

An article in the New York Medical Jommul of January 4, 1896, by Dr. W. D. Bratton of the U.S. Marine-Hospital Service, concerning the Arid Region Saritarium has attracted my attention. One would infer from this article that the idea of a national sanitarium for consumptives originated in the MarineHospital Service, either through Surgeon-General Woodworth, Surgeon-General Hamilton or SurgeonGeneral Wyman. I have examined the historical sketch of Surgeon Stoner in the annual report of the Marine-Hospital Service for 1893, but I am unable to discover therein any special reference to a national sanitarium for consumptives. Wishing to investigate the history of this movement for a national sanitarium, I wrote to the Marine-Hospital Service as follows:

To the Surgeon-General of the U. S. M.-H. Service.

Sir:-I am very much interested in a contribution by $\mathrm{Dr}$ W. D. Bratton, concerning an arid-region sanitarium in the New York Medical Journal of Jan. 4, 1896. From several sources I have understood that the plan for a national sanitarium for consumptives originated with Surgeon-General Wyman of the United States Marine-Hospital Service. I am deeply interested in this matter and would be very glad to know the truth concerning the priority of literature bearing on this subject.

In contributions to medical journals, magazines, annuals, lectures, etc., I have for many years labored to bring this about. I have succeeded in interesting representatives, senators, and even the family of one of the presidents of the United States.

In 1891, General Cogswell, of Massachusetts, introduced a bill which I prepared and furnished to him. Later, in 1892, Senator Gallinger, of New Hampshire, introduced a joint resolution bearing on the same subject.

Some of the articles which I have published concerning a national sanitarium are in the following: The New York Medical Journal, May, 1881; The Sanitarian, May, 1883; Archives of Medicine, October, 1884 ; the Philadelphia Medical Times, February, 1885, and The International Medical Annual, 1891; also the Philadelphia Medical Times, 1892, besides some other items, lectures, etc.

If your communications or those of any other physicians antedate these, will you kindly inform me? I would be greatly obliged to you if you will furnish me with reports of SurgeonGeneral Woodworth and Surgeon-General Hamilton on this subject:

The following is the reply:

W ashington, D. C., Jan. 30, 1896.

Dr. W. T. Parker, Groveland, Mass.

Sir:- In reply to your request of January 26 , I send you Annual Report of the Marine-Hospital Service for 1893.

Regarding my own interest in the sanitarium and the arid regions of Arizona, I have only to say that the idea suggested itself to me while on duty as Surgeon at the Marine-Hospital at St. Louis, where I served from 1876 to 1879 . I began some preliminary correspondence at that time relative to the matter, and personally urged it and made inquiries as to the most favorable location. When Dr. Bratton went south on "waiting orders' on account of pulmonary tuberculosis, I asked him to further investigate the subject. Respectfully yours,

WALTER WYMAN,

Supervising Surgeon-General, M.-H.'S.

The Surgeon-General, Dr. Wyman, does not state whether he published any article concerning a sanitarium for consumptives, and I should infer that he confined his remarks to official correspondence with the Marine-Hospital Service. Neither does he state when Dr. Bratton went south. I should infer that it is the Arizona climate which he has in mind and which I have never recommended. I have been unable to find any reference to the climate of New Mexico, which I do recommend. I do not wish to be understood as intimating that Dr. Wyman makes any claim to which he is not justly entitled. It is merely interesting to consider the priority of the plan for a national sanitarium. If corresponding alone entitles to priority, I might say that in 1867, while serving in New Mexico, I repeatedly corresponded concerming its healthfulness as others have done before and since. What I wish to get at is : Where do we find the first printed reports in our medical journals or in the secular press concerning a national sanitarium for consumptives? I inclose a letter received from the Executive Mansion, Feb. 4, 1891, concerning the bill which General Cogswell introduced at my request for the creation of a national sanitarium for consump. tives. I also inclose a letter received from General Cogswell, in March, 1892, and a letter received trom the manager of the General Butler estate, November, 1895. Through the courtesy of Mr. Flower, the editor of the Arena, I am permitted to furnish a portion of the proof sheets of an article concerning "A National Sanitarium for Consumptives," which I have written. The following is a quotation therefrom:

"With consumption so prevalent in the United States, is there nothing our government can do to 